\title{
Cioty, duchy, zmory jako ginący element języka i kultury ludowej okolic Gniezna
}

\author{
Cioty, duchy, zmory as a dying element of the \\ language and folk culture around Gniezno
}

\author{
||Justyna Kobus
}

\begin{abstract}
The article presents the results of dialectological and ethnographic research of an educational project concerning the holidays, beliefs and superstitions in the region of Gniezno. Objectives of the project and the problems associated with fieldwork were discussed. Thanks to the joint research of dialectologists and students, we managed to obtain a material that would enable the description of changes in the thematic, among others, magic and folk demonology. Analysis of selected examples is presented in the article.
\end{abstract}

Key words: dialectology, ethnography, educational project, thematic field

Streszczenie: W artykule zostały zaprezentowane wyniki badań dialektologiczno-etnograficznego projektu edukacyjnego dotyczącego świąt wierzeń i przesądów w okolicach Gniezna. Omówiono założenia projektu oraz problemy związane z badaniami terenowymi. Dzięki wspólnym badaniom dialektologów i uczniów udało się uzyskać materiał umożliwiający opis zmian między innymi w mikropolu tematycznym magia i demonologia ludowa. Analiza wybranych przykładów została przedstawiona w artykule.

Słowa kluczowe: dialektologia, etnografia, projekt edukacyjny, pole tematyczne

Artykuł ten związany jest z ukazaniem się Słownika języka mieszkańców okolic Gniezna. Święta, wierzenia i przesądy (Kobus, Gniazdowski 2018), będącego efektem dwuletniego projektu edukacyjnego, w którym współpracę z Instytutem Filologii Polskiej UAM i Pracownią Dialektologiczną podjęły 3 szkoły podstawowe z terenu gminy Gniezno ${ }^{1}$, a którego byłam koordynatorem naukowym. Badaniami objęto obszar zajmowany przez gminę Gniezno - w uproszczeniu: okolice Gniezna.

\footnotetext{
1 Mowa o następujących jednostkach edukacyjnych: Szkoła Podstawowa im. ks. Leona Formanowicza w Modliszewku, Zespół Szkół (do końca roku szkolnego 2016/2017 Zespół Szkolno-Gimnazjalny) im. ks. Jana Twardowskiego w Szczytnikach Duchownych, Szkoła Podstawowa im. Obrońców Gniezna i Ziemi Gnieźnieńskiej w Goślinowie.
} 
Każdy projekt edukacyjny ma na celu wspomaganie procesu dydaktycznego w zakresie wiedzy o regionie, lokalnym języku i kulturze. Są to działania polegające na popularyzacji nauki o regionie oraz ukierunkowane na rozwijanie zainteresowania uczniów swoją najbliższą okolicą, tzw. małą ojczyzną.

Projekty, które dotychczas prowadziłam, obejmowały następujące zadania podstawowe: badania terenowe wykonane przez dialektologów i uczniów (dodam, że zaangażowani byli - w pierwszym projekcie - gimnazjaliści oraz - w następnych - uczniowie szkół podstawowych), lekcje o gwarach i kulturze ludowej prowadzone przez pracowników Pracowni Dialektologicznej UAM, praca uczniów na transkrypcjach własnych nagrań (m.in. typowanie haseł słownikowych, poznanie struktury artykułu hasłowego wraz z podstawowymi pojęciami, tworzenie artykułów hasłowych do słownika regionalnego, rozpoznawanie elementów gwarowych w przetranskrybowanych tekstach), pozyskiwanie dokumentacji fotograficznej do badanego tematu (praktyczne łączenie działań o charakterze dialektologicznym i etnograficznym). Uczniowie mają możliwość konfrontacji wyników własnych badań z pracą dialektologów, gdyż przy każdej takiej współpracy proponuję odwiedziny w Pracowni Dialektologicznej, gdzie uczniowie zapoznają się z historią badania gwar wielkopolskich poprzez bezpośredni kontakt $\mathrm{z}$ archiwaliami fonograficznymi i dokumentacją papierową, poznają najważniejszą literaturę przedmiotu, mają możliwość zapoznania się z wieloma artefaktami z zakresu szeroko rozumianego folkloru (nie tylko wielkopolskiego, ale i z innych regionów, a nawet innych krajów słowiańskich). Dodatkową aktywnością jest organizacja galerii obrazującej poszczególne etapy projektu - pomysł ten w dużej mierze zależy od dostępnych środków finansowych, choć w pierwszym projekcie (Ocalić od zapomnienia - badamy język mieszkańców wsi gminy Czerniejewo, rok szkolny 2015/16 - zob. Kobus, Stępień 2018) udało nam się taką wystawę zorganizować i pokazać zarówno podczas uroczystego zakończenia projektu w szkole, jak i w Collegium Maius w Poznaniu na Wydziale Filologii Polskiej i Klasycznej UAM.

Najważniejsze w każdym projekcie edukacyjnym jest przygotowanie uczniów do efektywnego przeprowadzenia badań terenowych. Nie jest to zadanie łatwe z uwagi na nieprzewidywalność, którą niesie ze sobą charakter tej pracy - nagrywanie rozmowy. Uczniowie otrzymują szczegółowe instrukcje co do sposobu przygotowania nagrania tak, aby miało ono wartość archiwalną, naukową (językową, kulturową) oraz techniczną. Każdy uczeń-eksplorator wyposażony jest w kwestionariusz do nagrań, zawierający zestaw pytań dotyczących badanego tematu. W zdecydowanej większości uczniowie dostarczają dobre nagrania różnej długości, które kwalifikują się do wykorzystania w publikacji zamykającej projekt (słownik). Zdarza się jednak, że uczniowie (zwłaszcza ci młodsi) są wyręczani w zadawaniu pytań przez swoich informatorów, którzy sami odczytują kwestię, 
a następnie wypowiadają się na zadany temat; bywa i tak, że informator (szczególnie gdy jest to krewny ucznia), zamiast samodzielnie udzielać odpowiedzi, wypowiadać się spontanicznie, odczytuje fragment dostępnej publikacji dotyczącej tematu - jak łatwo się domyślić, nie o takie poświadczenia staramy się w projekcie (szerzej zob. Kobus 2017).

W każdym projekcie uczniowie proszeni są o wykonanie zdjęć związanych z badaną tematyką. Także i do tego przedsięwzięcia młodzi badacze otrzymują wskazówki dotyczące sposobu wykonywania fotografii, by były one wartościowym dokumentem etnograficznym i spełniały wymogi umożliwiające ich publikację w słowniku.

Do bezpośredniej współpracy przy powstaniu kończącego projekt słownika zapraszałam nauczyciela-koordynatora (opiekuna uczniów), który stawał się współredaktorem leksykonu. Zadaniem nauczyciela jest napisanie charakterystyki badanego terenu. Przyjęcie takiego rozwiązania sprawia, że każdy słownik różni się od poprzedniego, ponieważ każdy nauczyciel zwraca uwagę na inne zalety swojej najbliższej okolicy. Przykładowo, w projekcie dotyczącym świąt, wierzeń i przesądów, w którym koordynatorem wewnętrznym (opiekunem uczniów) był historyk (i anglista zarazem), wstęp do słownika został wzbogacony opisem zbadanych miejscowości w perspektywie dziejowej (nauczyciel sięgnął do archiwów, odnajdując najstarsze wzmianki o maleńkich niekiedy wsiach, kończąc tę charakterystykę opisem obecnej sytuacji społeczno-ekonomicznej poszczególnych punktów badawczych).

Każdy projekt staramy się zamknąć bardzo poważnie. Podczas uroczystości nie brakuje przedstawicieli władz gminnych oraz współpracujących stron, są obecni uczniowie z rodzinami i nasi informatorzy. Nie stronimy również od lokalnych mediów. Traktujemy je jako dodatkowe medium promowania wiedzy o regionie.

W niniejszym artykule chciałabym unaocznić, jak istotne korzyści naukowe przyniósł ostatni projekt, który zaowocował Słownikiem języka mieszkańców okolic Gniezna... (Kobus, Gniazdowski 2018). Analizie poddałam niewielki wycinek pozyskanego materiału z zakresu magii i demonologii ludowej.

Nadmienię, że badania na tym obszarze prowadził przed wojną Adam Tomaszewski (Tomaszewski 1930), lecz - jak wiadomo - wiele materiałów przepadło bezpowrotnie podczas II wojny światowej. Następnie język i kulturę ludową badał w okolicach Gniezna Zenon Sobierajski. Wyniki tych eksploracji zawarł w licznych publikacjach, z których warto wymienić Teksty gwarowe ze środkowej Wielkopolski (Sobierajski 1995) czy współredagowane 11-tomowe dzieło dialektologiczno-etnograficzne Atlas języka i kultury ludowej Wielkopolski (dalej: AJKLW). Miejscowości, które dziś należą do powiatu gnieźnieńskiego, a były punktami badawczymi Sobierajskiego, to: Niechanowo (1953 rok), Żydówko-Łubowo (1977 rok), punkty atlasowe - Ostrowite Prymasowskie (1975 rok, punkt 35a AJKLW) oraz Obora (lata 
70., punkt 35 AJKLW i w latach 80. materiały zbierane do pracy magisterskiej przez Elizę Grzelak). Warto w tym miejscu wymienić dwa artykuły poświęcone nazwom i obyczajom związanym z podstawowymi świętami - Henryka Nowaka Obrzędowa (wigilijna) nazwa gwiazdor i synonimy w Wielkopolsce (Nowak 1999) ${ }^{2}$ oraz Jerzego Sierociuka $Z$ problematyki regionalizmów językowo-kulturowych: zając (Sierociuk 2010). Kolejne materiały terenowe z powiatu gnieźnieńskiego pozyskiwane były sporadycznie (okazjonalnie) po $2000 \mathrm{r}$. w ramach zajęć akademickich i pojedynczych eksploracji pracowników Zakładu Dialektologii Polskiej UAM, a następnie Pracowni Dialektologicznej UAM ${ }^{3}$.

W etnograficznej charakterystyce literatury opisywanego terenu nie sposób pominąć XIX-wiecznych badań obrzędowości ludowej Oskara Kolberga. W tomie XI Kolberg opisał zwyczaje ludności ówczesnego powiatu gnieźnieńskiego, a w nim miejscowości: Gniezno, Niechanowo, Witkowo, Karsewo, Czerniejewo, Kłecko, Powidz, Mielżyn, Kiszkowo, Żydowo, Chłędowo, Dziećmiarki, Małachowo Wierzbiczane, Wilkowyja i Modliszewko (obrzęd wesela - pieśni). Następnym przyczynkiem do poznania kultury ludowej były dzieła XX-wieczne: tuż po wojnie rozpoczęto prace nad Polskim Atlasem Etnograficznym (Gajek 1964-1981) z siatką punktów badawczych uwzględniających powiat i gminę Gniezno (Kłodnicki 2002) oraz wspomniany wcześniej Atlas języka i kultury ludowej Wielkopolski (AJKLW - tylko 2 punkty badawcze z powiatu gnieźnieńskiego). Z opracowań szerzej opisujących interesującą nas problematykę nie do przecenienia jest 3-tomowe dzieło pod redakcją Józefa Burszty Kultura ludowa Wielkopolski, szczególnie tom III, poświęcony zwyczajom i obrzędom wielkopolskim (także okolic Gniezna), oraz monografia Andrzeja Brencza Wielkopolski rok obrzędowy. Tradycja i zmiana (Brencz 2006), w której autor wyraźnie podkreśla przeobrażenia, jakim uległa kultura ludowa w czasach nam współczesnych (u progu XXI w.). W ostatnim czasie ukazała się publikacja Aleksandry Paprot Powiat gnieźnieński. Atlas niematerialnego dziedzictwa kulturowego wsi wielkopolskiej (Paprot 2015) - jest to pozycja stricte etnograficzna i jako jedyna uwzględniająca dość obszernie teren, na którym wraz z uczniami realizowaliśmy projekt językowo-kulturowy (częściowo nasze obserwacje pokrywają się z wynikami badań Paprot).

Z uwagi na fakt, że finalizujące projekty edukacyjne słowniczki powstające w Pracowni Dialektologicznej UAM traktujemy po części jako wstęp do słownika ogólnowielkopolskiego (o czym często informuje Jerzy Sierociuk - zob. Sierociuk 2016, 245-254), po części zaś jako zbiór materiałów wymagających szerszego komentarza, a wręcz dodatkowego opracowania monograficznego, artykuł ten traktuję jako komentarz cząstkowy do

${ }^{2}$ W naszym słowniczku traktujemy określenie Gwiazdor jako nazwę własną, analogicznie do Święty Mikołaj czy Dziadek Mróz, z tego też powodu hasło to zapisujemy wielką literą, mimo że zasada ortograficzna mówi inaczej.

3 Szczegółowe zestawienie materiałów dialektalnych z okolic Gniezna (zarówno w zbiorach PD UAM, jak i kartoteki SGP PAN w Krakowie) przedstawił J. Sierociuk (Sierociuk 2018). 
prezentowanego Słownika... Zamierzam tu zrelacjonować stan współczesny słownictwa i elementów kultury zastany na badanym terenie oraz - na ile to będzie możliwe - przywołać wyniki badań wcześniejszych.

Dotychczas, w ramach warszawskich konferencji z cyklu Dialog pokoleń, miałam okazję poczynić uwagi na prawach komentarza do powstającego wówczas słownika (dziś jest to artykuł dotyczący m.in. ewolucji nazw i desygnatu Gwiazdor i in. w mowie mieszkańców okolic Gniezna; por. Kobus 2017, 135-142 i Kobus 2018, 99-111). Tym razem chciałabym się odnieść do pozyskanej w terenie dokumentacji językowej i kulturowej dotyczącej zjawisk nadprzyrodzonych konotowanych negatywnie i tego, co z nimi związane, czyli rekwizytów, sposobów funkcjonowania zła, sposobów radzenia sobie ze złem itd.

Podczas badań terenowych zespół eksploratorów (uczniowie i dialektolodzy) napotkał na rozmaite trudności. Szczególnie uciążliwą do pokonania okazała się bariera związana z tematyką rozmów. Zdarzali się bowiem informatorzy, którzy nie chcieli opowiadać o kuszeniach i czarach z przyczyn religijnych. Ale też znalazły się osoby chętnie wypowiadające się na zadany „nadprzyrodzony” temat.

Pozyskane $\mathrm{w}$ ten sposób materiały można podzielić wstępnie na 3 grupy: nazwy istot nadprzyrodzonych oraz bytów o znamionach zła, rekwizyty związane z mocami nadprzyrodzonymi (atrybuty i cechy desygnatu), zwyczaje związane $\mathrm{z}$ unikaniem zła i/lub jego rugowaniem.

Przejdę do prezentacji materiału.

W grupie pierwszej, zawierającej nazwy istot nadprzyrodzonych oraz bytów o znamionach zła (istoty sprowadzające/niosące zło), zebraliśmy następujące poświadczenia: ciota/czarownica, diabeł, duch/dusza, postać/ zmora, zmarły/trup, zazdrośni ludzie, kobieta w ciąży, czarny kot, mysz.

W materiale rozpoznać można postacie, które od dawna są elementem kultury ludowej mieszkańców okolic Gniezna (występujące także szerzej), jak ciota identyfikowana ogólnie z czarownica 'osoba odznaczająca się złymi, tajemnymi mocami; rzucająca uroki, czary za pomocą wzroku lub intencji', znana w wielu regionach Polski zmora 'zjawa dusząca człowieka podczas snu, często utożsamiana z duszami zmarłych domagających się modlitwy' oraz ogólnie kojarzone istoty, jak diabeł 'postać niosąca zło i nieszczęście, skłaniająca ludzi do czynienia zła, wysłannik piekieł, czart; tu także: zjawa dusząca człowieka podczas snu' czy duch 'dusza potępiona, błąkająca się po świecie, ponieważ nie może zaznać spokoju'. Ponadto istotami zawierającymi w sobie pierwiastek zła są: kobieta w cią̇y 'kobieta spodziewająca się dziecka; w tradycji ludowej kobieta ciężarna przynosiła pecha, ale przede wszystkim musiała uważać na wiele niebezpieczeństw ze strony złych mocy czyhających na jej nienarodzone dziecko, złego losu, niefortunnych zdarzeń; wiele $\mathrm{z}$ dawnych przekonań (dziś wprawdzie uznawanych za przesądy) nadal jest podtrzymywanych i żywych wśród kobiet oczekujących dziecka i ich rodzin', czarny kot 'zwierzę trzymane w gospodarstwach 
ze względu na umiejętności łowne (poluje na myszy); mycie się kota pełni funkcję przepowiadania wizyty gości - w zależności od tego, w którą stronę (którą łapką) kot ociera pyszczek, z tej strony przybędą goście; czarny kot jest zazwyczaj kojarzony z nieszczęściem, zwłaszcza gdy przebiegnie drogę nadchodzącemu człowiekowi', mysz 'gryzoń domowy; według lokalnych przekonań myszy czynią szkody, szczególnie w ubraniach, osobom, które odmówiły (pożyczenia) czegoś kobiecie ciężarnej'.

Prócz konkretnych nazw zauważyć można tendencję do używania określeń o charakterze opisowym, np. zazdrośni ludzie, zazdrosne oczy - cechy przypisywane ciotom - o ludziach 'świadomie lub bezwiednie sprowadzających na innych nieszczęście, pecha, niefart' lub nieokreślone bliżej sformułowanie postać odnoszące się do zmory 'zjawa, duch osoby zmarłej szukający kontaktu z żywymi'.

Jako przykład żywotności omawianych nazw i wierzeń nich posłuży wypowiedź informatorki z Modliszewa [PaE] ur. 1948 r. na temat zazdrosnych ludzi:

PaE: miałam tako ${ }^{\mathrm{m}}$ zazdrosno ${ }^{\mathrm{m}}$ so $^{\mathrm{n}}$ siadke ... ona już nie $\dot{z} y j e$... i kiedyś ... wie pan co ... no nie było gdzie miejsca te małe kurczaki trzymać to sie kawołek kuchni odgrodziło i te kurczaki były ... no i my te kurczoki z jednego dnia mielim i ona kiedyś weszła do mnie do domu i mówi tak [głęboki wdech] ... ale tak dosłownie zrobił [głęboki wdech] ... to $s^{\mathrm{m}}$ te kurczaki? ... mówie : no ... a ${ }^{\mathrm{u}}$ ona mówi: o jeju ... to moje so ${ }^{\mathrm{m}}$ połowe mniejsze ... ona wyszła ... wiesz pan jak te kurczaki zaczeły sie dzióbadź mie ${ }^{\mathrm{n}} d z y$ sobo ${ }^{\mathrm{m}}$ ... to by sie cholery wszystkie wykończyły ... i mi sie przypomniało ... bo my mówilim na nio ${ }^{\mathrm{m}}$ Lalunia ... to była ... jag mieszkałam $w$ Łabiszynku ... $i$ ona miała takie stare przeso ${ }^{\mathrm{n}} d y$... wie pan ... ale naprawde stare przeson $d y$... i ta Lalunia kiedyź mi mówi tak: słuchaj ... jak kiedyś ci ktoś tak zrobi to nic tylko myj tłuste talerze i to ${ }^{\mathrm{m}}$ ściero $^{\mathrm{m}}$ stań $\mathrm{i}$ wykre ${ }^{\mathrm{n}}$ caj i mówić: idź do diabła ... idź do diabła ... wypieprzaj sto ${ }^{\mathrm{n}} d$... i wie pan co? ... ja naprowde to zrobiłam ... no bo już nie mogłam patrzedź jak te stwory sie tego ... wierzy pan że za godzine sie wszystko naprawde uspokoiło? ... i przez to ja $w$ takie rzeczy ... sie śmiejo ${ }^{\mathrm{m}}$ ze mnie że jestem ... że lubie niektóre zababony (!)... ale ja mówie ja mam to sprawdzone ... i tak sobie jag ona mi tłumaczyła ... może to być całkiem śmieszne ... kiedyź mi chorowały proszczaki a właśnie jeszcze tam $w$ Łabiszynku mieszkalim ... i ona mówi tak: lalunia ... weź starego ślubne portki i tego proszczoka przepuść przez te portki ... no mówie: pani ... my już tyle lat po ślubie sko ${ }^{\mathrm{n}} d$ mam wzion ${ }^{\mathrm{n}}$ starego portki ślubne ... a ona poszła ... wierzy pan ... wzieła to ${ }^{\mathrm{m}}$ drapake ... tako miotłe na kiju z dżewa (!) i wzieła do tego tych właśnie pomyj i jakoś to ${ }^{\mathrm{m}}$ drapake trzymała i tymi pomyjami tak po tych proszczakach ... wierzy pan że dobrze to wszystko wyszło? ... i ... i .... ale to tylko ona jedna mi o tym mówiła i ja raz jedno ${ }^{\mathrm{n}} \mathrm{Cy}$... bo tyko tag ale $\mathrm{so}^{\mathrm{m}}$ ludzie zazdrośni i zachłanni ... niech pan wyda komuś kwiaty kto jes chytry na kwiaty ... 
panu wszystkie $w$ domu zmarniejo $^{\mathrm{m}}$ doniczkowe a tamten be ${ }^{\mathrm{n}} d z i e$ miał takie ... i $w$ te rzeczy to ja wierze ... (...)

Spośród powyższych nazw ciota, zmora i diabeł zostały opisane na mapach AJKLW-X ${ }^{4}$. Mapa 830 przedstawia rozkład nazw Czarownica i synonimy, z którego wynika, że ciota była w Wielkopolsce powszechnie stosowaną nazwą, ponadto w okolicach Gniezna obok cioty i czarownicy znanych współcześnie, można było napotkać wiedźmę (nazwy tej brak w materiałach słownikowych). Sam wyraz ciota pojawia się w AJKLW także w znaczeniu 'pogardliwie o kobiecie' oraz 'wiatr wirujący; trąba powietrzna' - współcześnie nie uzyskaliśmy poświadczenia dla tego znaczenia, ale prawdopodobnie wynikało to z faktu, że o zjawisko to nie pytaliśmy. W przypadku zmory zespół atlasowy opisał znaczenie wyrazów mora, zmora, wieszczyca na m. 829. Z ówczesnych badań wynika, że na terenie dzisiejszej gminy Gniezno ludność używała nazwy zmora w dwóch znaczeniach 1. 'zjawa, mara, dusząca człowieka we śnie', 2. 'nieznośna, zła kobieta; nieraz przezwisko' - obydwa poświadczone w badaniach współczesnych. Na mapie 825 rozpisano nazwy demonów diabolicznych - według danych atlasowych na badanym terenie występowały nazwy czart, szatan oraz poświadczony i dziś diabeł. Poniżej przytaczam współczesne wypowiedzi z przykładami dla tej grupy nazw:

Lubochnia (informatorki: [JuZ] ur. 1936 r., [RóŁ] 1938 r.)

No tak, potem się okazuje fakt jakiś. A czy jest taka nazwa, że jakaś zmora kogoś dusi w nocy?

JuZ: że tak jakby człowieka coś dusiło ...

RóŁ: tak ... teraz może nie tag ale kiedyś to tak było tu ... było godane że zmora dusiła ...

JuZ: ale nieroz też tak coś dusiło ... w nocy ...

\section{W nocy.}

JuZ: tak cien $\dot{z} k o$ sie na mnie połó̇yło i taagby taki diaboł jak coś ... i jo tak ... ale nie wim ... wie ${ }^{\mathrm{n}} \mathrm{c}$ tyż że tam sklyłam ... i wi ${ }^{\mathrm{n}} \mathrm{cy}$ już teygó nie ... czułam jak ze mnie zeszło ...

Modliszewko (informatorka [GóT] ur. 1948 r.):

GóT: a ... zmora ... no ... to to pamie tam ... nasza so ${ }^{\mathrm{n}} \operatorname{siadka~...~ona~ju\dot {z}}$

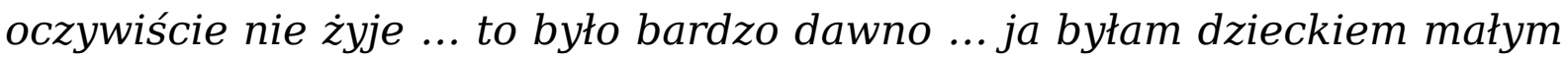
... w progu zostawiała miotłe ... tako ${ }^{\mathrm{m}}$ miotłe $z$ wierz... z witek ... takich ... takich gałonzek ... ja pytałam czemu ona tak stawia te miotłe i moja mama mi odpowiedziała że boi sie zmory która przyjdzie $w$ nocy $i$ jo $^{\mathrm{m}}$ dusi ... ale jaka zmora? ... sie śmiała ... mówi: dobrze by było żeby sie za siebie wzieła to by zmore udusiła ... ale co to miało znaczyć ... chodziło o to że miała troche lepkie re ${ }^{\mathrm{n}} \mathrm{ce}$ i dlatego ... (...) ale to pamie ${ }^{\mathrm{n}}$ tam $\dot{z}$ e ta so $^{\mathrm{n}}$ siadka tako ${ }^{\mathrm{m}}$ miotłe stawiała na skos żeby ta zmora jej nie dusiła $w$ nocy ... tak ... to pamie $^{\mathrm{n}}$ tam ... [...]

Rekwizyty związane ze złymi mocami (atrybuty i cechy desygnatu).

${ }^{4}$ Magii i demonologii ludowej dotyczy zaledwie 10 pytań. 
Świat nadprzyrodzony oraz nie mniej zagrażające człowiekowi siły natury trzeba niejako „oswoić”, by móc je poznać i bronić się przed ich działaniem. Wyekscerpowany materiał obejmuje rozmaite nazwy związane z wszystkim tym, czym odznaczają się wymienione już istoty oraz wszelkie przejawy działania szeroko pojmowanych złych mocy.

I tu również materiał można uporządkować według kilku grup:

- atrybuty sił nieczystych i istot niosących zło: granica (cioty), miotła [mietła] (cioty), umiejętność kuszenia (duchy zmarłych), myszy (kobieta cie $\left.{ }^{\mathrm{n}} \dot{a} a r n a\right)$;

- to, czego powinni wystrzegać się wszyscy: czar/urok, złe spojrzenie, drabina, czarny kot, niepochowanie zmarłych przed niedziela;

- to, czego powinna wystrzegać się kobieta w ciąży i noworodek: powyższe oraz zagladanie przez dziurkę od klucza, chodzenie pod linkami, noszenie miary krawieckiej na szyi, wystraszenie się myszy lub ognia, patrzenie na trupa/zmarłego, uczestniczenie $w$ pogrzebach, rozwieszanie pieluch na podwórku przed ochrzczeniem dziecka, niewyprowadzanie na dwór dziecka przed ochrzczeniem;

- to, czego powinni wystrzegać się gospodarze: rozpoczynanie ważnych prac w piatek i poniedziałek, sprzedawanie po zachodzie słońca/z chlywa.

Poprzednia grupa materiałów gromadziła nazwy istot pozostających po stronie zła. Z nimi związane są pewne miejsca, przedmioty, umiejętności. I tak, z ciotami bezsprzecznie należy powiązać miotłę/mietłę oraz granice (miedze), na których można je spotkać. Natomiast umiejętność kuszenia właściwa jest osobom zmarłym, a właściwie ich $d u c h o^{\mathrm{m}} / d_{u s z o^{\mathrm{m}}}$. Z kolei kobieta $\operatorname{cie}^{\mathrm{n}} \dot{z} a r n a$ sprowadzi plagę myszy na osobę, która odmówi pożyczenia jej czegoś:

Modliszewo (informatorka [PaE] ur. 1948 r.):

PaE: (...) przychodzi Cyganka a my zabilim świniaka i jo robiłam sobie wyroby ... nie ... a że jo wszysko sama se robie to te wyroby też ... tutaj miałam na kołku powieszone te kiełbasy a ona przylazła a byłam sama $w$ domu ... i ona mówi: dej se powróżyć ... a idź do diabła mówie ... ja wróżyć se nie potrzebuje co los przyniesie to by $y^{\mathrm{n}} d z i e$... to dej kiełbasy ... to se zarób ... a ona mówi: ale ja jestem $w$ cion $\dot{z} y$... i mówi: i ci myszy zeźro ${ }^{\mathrm{m}}$... a ja mówie: srajo $^{\mathrm{m}}$ muchy by ${ }^{\mathrm{n}} \mathrm{dzie}$ wiosna ... ale wziłam kawałek kiełbasy i dałam ... ale daj jeszcze dla mojego chłopa ... ty jesteś w cionży a twój chłob nie ... mówie ... do widzenia ... bo taka ... do strachliwych to ja nigdy nie należałam ale dałam ... dałam ... no bo co ... jag miały mi myszy coś poźryć to co? ... no i tak było że jag nieroz myszy ... przecież na gospodarstwach to te domy nieszczelne ... nie ... tego ... myszy pojadły to zawsze mówili: no ... bo żeś któryś tam czegoź nie dała i ci przez to myszy ...

Zasadniczo wszyscy ludzie powinni mieć się na baczności w każdym momencie żywota codziennego i wystrzegać się zarówno osób o złym 
spojrzeniu, jak i konkretnych zachowań (np. dotyczących pochówku) czy przedmiotów codziennego użytku (np. drabina). Dlaczego tak się dzieje, opowiedzieli nasi informatorzy. Otóż, ludzie o złym czy też zazdrosnym spojrzeniu mogą rzucić urok względnie czar świadomie lub całkowicie bezwiednie. Przejście pod drabina może przynieść pecha w danym dniu (podobnie działa czarny kot, jeśli przebiegnie komuś drogę), a gdy zmarły nie zostanie pochowany przed niedzielą, niechybnie spowoduje śmierć kolejnej osoby z najbliższego otoczenia, spośród żałobników. Szczególnym celem złych mocy są kobiety w ciąży i ich dzieci narodzone lub jeszcze nienarodzone oraz gospodarze (sąsiedzi, sąsiadki). Na kobietę w ciąży czeka niezmiernie dużo zasadzek, które mogą zaszkodzić noszonemu dziecku. Przyszła matka sama może sprowadzić nieszczęście na dziecko poprzez: zaglondanie przez dziurkę od klucza, chodzenie pod linkami, noszenie miary krawieckiej na szyi (w przypadku gdy jest krawcową), patrzenie na trupa/zmarłego, uczestniczenie $w$ pogrzebach, rozwieszanie pieluch na podwórku przed ochrzczeniem dziecka, wyprowadzanie na dwór dziecka przed ochrzczeniem lub też przyczyną nieszczęścia może być niefortunny przypadek jak przestraszenie się myszy lub ognia, co powoduje różne znamiona (myszka, płomień/ogień) na ciele dziecka, albo też zło może przyjść bezpośrednio od innych osób w postaci uroku/czaru/ociotowania.

Natomiast gospodarze winni wystrzegać się przede wszystkim sprzedawania po zmroku oraz sprzedawania z chlywa i wpuszczania obcych do chlywa. Transakcje kupna-sprzedaży należy zawierać za dnia, a sprzedane zwierzęta powinno się wprowadzić na wóz, by nie wychodziły bezpośrednio z zabudowań, które zamieszkują. Oto relacja informatorek ze Szczytnik Duchownych ([KęJ] ur. 1936 r., [JaS] ur. 1922 r., XxX - kobieta ok. 50 lat $^{5}$ ):

\section{Szczytniki Duchowne:}

Można było po zachodzie słońca kupować, transakcje zawierać?

KęJ: nie nie ...

XxX: nie ... po zachodzie słońca nie można było nic sprzedawać ... nie? ... ma ...

KęJ: nidz nig nie sprzedał ... ani świni ani krowy ani to ... to już tego ni

$\mathrm{XxX}$ : a jeżeli coś sprzedał to nie mógł odprowadzać ... bo odprowadził szcze ${ }^{\mathrm{n}}$ sie ...

JaS: a tak ...

$\mathrm{XxX}$ : nie? ...

JaS: no ... mój brat ${ }^{\mathrm{u}}$ odprowadził ...

KęJ: z chlywa nie wolno sprzedawać ... bo czy tak czy siak ... nie ... jak tegó to na wóz ... na wozie czy jak tam ...

$\mathrm{XxX}$ : wyjechać ze swojego gospodarstwa? ...

${ }^{5}$ Nie wszyscy informatorzy podają dane osobowe, chcąc pozostać anonimowymi uczestnikami badania. 
KęJ: nie ... na wozie ... ten ktoś $z$ wozu mógł wziońć ... nie ... ze z chlewa to nie ... bo to szcze ${ }^{\text {n }}$ cie tam ...

JaS: człowiek prowadzi po zachodzie słońca tam albo chociażby $w$ dziń

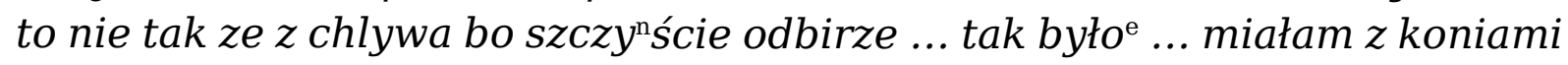
tak ... a późni $z$ krowo $^{\mathrm{m}}$...

KęJ: no no ... to prawda ...

JaS: a świnie tyż tag miałam ...

KęJ: może to prawda może nie ... już tam ...

XxX: coś $w$ tym musi być ...

JaS: jag nie byłam na gospodarce ... nie ... miałam swoje ... koników(?) dwa i tam $\mathrm{mo}^{\mathrm{n}} \dot{z}$ prowadził jednygó człowieka ... tam miały może po czterdziści kilo ... zżarły wszysko ... a jak ten człowiek "odszed świnie miały $w$ korycie żarcie ... po... żarcie mogło $w$ korycie cały dziń być ... półowa została kwiczały ... no do ... może tak do centnara ... szejśdzisiont kilo ...

KęJ: bo to ludzie zazdrośni ... to na wiosce byli bardzo zazdrośni ... nie ... takie zazdrosne $\dot{z}$ e o Jezu ... jedyn drugimu a już tyn troche wie ${ }^{\mathrm{n}} \mathrm{Cy}$ miat ... nie ... to już już tegó ... każdy sie ten ...

JaS: wieczorym już sie do budynku obcyh ludzi i nie sprzedaje ... bo tyn człowiek nawed nie wi $\dot{z} e^{\text {u}}$ on tam może zaszkodzidź a jak ... tag jakby ...

KęJ: jakom ${ }^{\mathrm{m}}$ site ma ...

JaS: zazdrościł czy co ... ja nie wiem ...

Tylko niektóre pozyskane współcześnie nazwy z tej grupy były przedmiotem opisu AJKLW. Zmapowano raczej nazwy z kategorii: ogólne. Zatem mapa 832. Urok albo przyrok i inne synonimy - na mapie widzimy, że okolice Gniezna objął zwarty zasięg nazwy ociotowanie (ociotanie), przy czym granica zasięgu przebiega dokładnie przez środek miasta (a zarazem i gminy), niemniej jednak po obu stronach granicy zasięgu odnotowano także nazwę urok, która wraz z ociotowaniem/ociotaniem funkcjonuje na tym terenie do dziś (w materiałach słownikowych jest także poświadczenie dla wyrażenia coś zadoć w sensie rzucić urok). Mapa 833. Rzucić urok albo przyrok - tu dla naszego terenu poświadczono nazwę ociotować, względnie przyroczyć - obydwie zostały współcześnie odnotowane obok rzucić urok. Natomiast na mapie 834. Usunąć urok albo przyrok dla okolic Gniezna zanotowano: oduroczyć, odżegnać, odczynić, od(u)roczyć. Warto zaznaczyć, że w badaniach współczesnych pojawiła się nazwa odczyn oznaczająca czynności związane ze zdjęciem uroku.

Zwyczaje związane $\mathrm{z}$ unikaniem zła i/lub jego rugowaniem.

Kultura wsi wbrew współczesnemu wrażeniu chaosu, jest bardzo uporządkowana. Zasada związana z radzeniem sobie ze złem jest prosta - skoro istnieje urok - musi być sposób na jego zdjęcie, jeśli jest choroba - musi być na nią lekarstwo, jeśli zagraża domostwu natura - znajdzie się sposób na uchronienie się przed jej skutkami itd. Skoro dotyka nas nieszczęście, to w równej mierze odpłaci nam los szczęściem. Równowaga - tak jak 
w przyrodzie, tak i w kulturze - być musi. Jakie zatem mieszkańcy wsi znają dziś środki zaradcze przeciwko szeroko rozumianemu złu?

Materiał pogrupowałam w następujący sposób:

- przeciwdziałanie istotom nadprzyrodzonym: kadzidło, modlitwa, krzyż, zasłanianie luster, zatrzymywanie zegara, wynoszenie zmarłych $w$ odpowiedni sposób, odprowadzenie zmarłego, pochowanie przed niedzielo ${ }^{\mathrm{m}}$, włożenie odpowiednich przedmiotów do trumny osoby zmarłej;

- przeciwdziałanie urokom: chrzest, bozinka względnie kokardkal wsto $^{\mathrm{n}} \dot{z} e c z k a$ czerwona, metal, kciuk, skrzyżowane palce, bycie złym, klnien cie, czarcie żebro, drapaka lub miotła, siki, pomyje, lizanie (oblizanie) czółko dziecka, nitka $z$ pe telko ${ }^{\mathrm{m}}$ wrzucona do studni, ślubne portki, sierść;

- przeciwdziałanie chorobom: wianki, kadzidło;

- przeciwdziałanie nieszczęściom gospodarskim: siedzenie przy stole wigilijnym, niespanie $w$ Wielkanoc;

- przeciwdziałanie siłom natury: rozchodnik, gromnica, brzoza (gałąki brzozowe);

- przeciwdziałanie wszelakiemu nieszczęściu: modlitwa.

Kultura ludowa została silnie naznaczona wpływem religii chrześcijańskiej w postaci oddziaływania tradycji Kościoła katolickiego, toteż swoistym panaceum na wszelkie zło okazuje się kadzenie i świencenie wszystkiego, co się da, np.: świe ${ }^{\mathrm{n}}$ cenie palm, świen ${ }^{\mathrm{n}}$ cenie wianków, świe ${ }^{\mathrm{n}}$ cenie pokarmów, świen ${ }^{\mathrm{n}}$ cenie bukietów. Ponadto niebanalne znaczenie mają: chrzest, krzyż, gromnica, obraz (świenty).

Wśród osób, które wzięły udział w badaniu, znalazła się grupa informatorów-racjonalistów, którzy uznali tę część pytań za: tradycje, wierzenia, zabobony, zwyczaje, przesady itd. Nie wszyscy do końca byli wierni tej tezie, można więc uznać ich „racjonalizm” za formę obrony przed tym, co niebezpieczne, a nieznane i niezrozumiałe, jako unikanie wypowiadania się na niewygodny temat.

Człowiek z natury będąc podejrzliwy i nieufny, w walce ze złem stawia zwykle na więcej niż jeden środek zaradczy. W zebranym materiale możemy zaobserwować łączenie tradycji ludowych z tradycją kościelną (chrześcijańską) na zasadzie Panu Bogu świeca, a Diabłu ogarek. Przejawia się to chociażby w stosowaniu bozinki przeciw urokom rzucanym na noworodka czy poświęconych podczas Bożego Ciała gałąek brzozowych przeciwdziałających robactwu w uprawach (szczególnie kapusty) oraz zapewniających pomyślność w uprawie zbóż po wbiciu ich w pole uprawne. Warto też nazbierać ziół i poświęcić zrobione z nich wianki i bukiety, by wykorzystać je do leczenia chorób (często o nieznanym pochodzeniu, będących skutkiem uroku). Szczególnie ważnym dla gospodarzy jest siedzenie (nieodchodzenie) przy stole wigilijnym oraz niespanie (rezygnacja z drzemki) 
w Wielkanoc, co ma zapewnić dobre niesienie się kur i pomyślność w uprawie oraz udany zbiór siana.

Mamy tu też do czynienia ze sporą grupą zabiegów stricte ludowych, a na pewno świeckich, które pomagają uniknąć złego oddziaływania złych mocy: zasłanianie luster i zatrzymywanie zegara w pokoju lub domu, gdzie znajduje się ciało osoby zmarłej, wynoszenie zmarłych $w$ odpowiedni sposób (nogami do przodu, głowa opuszcza dom jako ostatnia część ciała), odprowadzenie zmarłego do krzyża lub figury znajdujących się na końcu wsi lub w jej centrum (symboliczne pożegnanie zmarłego z wsią, w której się urodził, żył i umarł), pochowanie przed niedzielom, włożenie odpowiednich przedmiotów do trumny osoby zmarłej (współcześnie zwyczaj ten zdobywa coraz większą popularność) lub skrzyżowanie palców albo klnie ${ }^{\mathrm{n}} c i e$, względnie bycie złym, przechodząc obok cioty.

Jeśli jednak zostanie na człowieka rzucony urok, nieszczęście lub pech prześladuje zarówno ludzi, jak i inwentarz gospodarski, a metody chrześcijańskie (kadzenie, świen ${ }^{\mathrm{n}}$ cenie) nie pomagają, należy sięgnąć po arsenał ludowych środków zaradczych. W zależności od problemu stosuje się: metal (by piorun nie zabił piskląt), zlizywanie (oblizywanie) czółka dziecka (zdjęcie uroku z małego dziecka), nitke $z$ pe telko $^{\mathrm{m}}$ wrzucono $^{\mathrm{m}}$ do studni lub/i kąpiel w czarcim żebrze (ostrożeń żebrowy) - w celu zdjęcia uroku z ludzi w każdym wieku, ślubne portki i/lub drapaka czy miotła zanurzane w sikach (w celu zdjęcia uroku z trzody chlewnej), sierść (zdjęcie uroku z krów).

Barwnie o tych metodach opowiedziały informatorki z Lubochni ([Ke्J] ur. 1936 r., [JaS] ur. 1922 r., XxX - ok. 50 lat) i Modliszewa ([PaE] - ur. 1948 r.).

\section{Lubochnia}

KęJ: nie ... to nie ... tylko wiem jagja ... tu na Wierzbiczanach ... takie były ... bo to Urbanioczka była ... ta Zielińsko stara i jeszcze ... trzy takie stare kobity były na tych Wierzbiczanach ... nie ... no to óne zawsze jak czwarta gódzina $w$ nocy czy tam rano ... nie ... to one już latały po ty granicy ...

$\mathrm{XxX}$ : to czarownice były? ...

KęJ: no ...

XxX: tak? ...

KęJ: no ... tak ... tak ... to były takie ... bo ja to widziałam ...

\section{Pani mówi...}

SaJ: ja wiem ... takie ... rychło rano ... no ...

KęJ: że jak sie koło nich szło ... nie ... koo tych ... jak tam nieraz szłam na Wierzbiczany ona tam mieszkaa ... nie ... to moja mama mówi: weź te dwa palce tak sobie złóż i bo $o^{\mathrm{n}} d \dot{z} z \nmid a$... żeby nie te ... bo cie ociotujo ${ }^{\mathrm{m}} .$.

\section{Za kciuki się chwycić.}

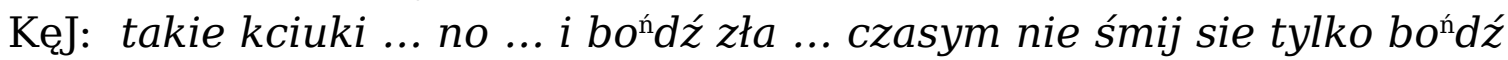
zła bo cie o...

Modliszewo

PaE: a najlepiej to obcych do chlewa nie wpuszczać ...

\section{Dlaczego?}


PaE: bo ociotujo ${ }^{\mathrm{m}}$... to znaczy zbieraj... proszczaków sie nie sprzedaje $z$ chlewa bo panu wszysko zabioro ${ }^{\mathrm{m}}$ szcze $^{\mathrm{n}}$ ście i wszysko i panu nidz nie pójdzie na re ${ }^{\mathrm{n}} k e . .$.

\section{W jaki sposób się odbywało to handlowanie?}

PaE: a najlepiej to sie wynosiło na próg od chlewa proszczoka za dwi nogi ... na przodnich (!) szedł sam ... tylnie sie mu ... i tego ... i ... no bo ja to tam tylko dwa razy sprzedawałam ... ale na trzeci to jechałam na targ kupowadź normalnie ... (...)

PaE: z tym wynoszeniem szczy ńsia to jes ... a jajka od kur ... niech by pan wydał komuź jajka i nie wzioł chociaż pan złotówki za te jajka ... na przykład jak ktoź mówi tak: oj bo ty masz fajnego koguta ... daj mi do nasadzenia kury i ... i jajka ... nie ... to chociaż złotówke ale niech położy i niech zapłaci ... za darmo nie ma ... i ... bo dlaczego ... sie rozchodzi żeby nie zabrać panu szcze ${ }^{\mathrm{n}}$ ścia ... no ... to so $\mathrm{s}^{\mathrm{m}}$... wie pan ... to so ${ }^{\mathrm{m}}$ zababony (!) ale to ludzie przeszli przez to kupe lad i oni wiedzo ${ }^{\mathrm{m}}$...

W AJKLW zasadniczo pytano o odczynianie zła wyrządzonego zwierzętom hodowlanym, a nie ludziom. Poświadczenia te należały już wtedy do rzadkości. W komentarzach do AJKLW-X czytamy:

Badania terenowe pozwoliły uchwycić nieliczne relikty magii i demonologii. (...) W zebranym materiale można jeszcze znaleźć niektóre zanikające formy magii, a mianowicie: a) magię czynności, jak okadzanie dymem z ziół, wypędzanie choroby przez symboliczne bicie zwierzęcia, zmywanie choroby brudną wodą i spluwanie; b) magię słowa, jak wypowiadanie wierszowanego zaklęcia lub liczenie wstecz (magia liczby 3 i 9) (AJKLW-X, cz. 2. s. 15).

Niektóre z tych praktyk są współcześnie kontynuowane, choć nie zawsze w taki sam sposób, w jaki zaobserwowali to eksploratorzy z zespołu AJKLW (np. wianki z ziół wykorzystywane do kadzenia, przeklinanie cioty czy ścieranie uroków/chorób za pomocą miotły z użyciem różnorakich cieczy itp.). Nie ma w AJKLW mapy bezpośrednio opisującej praktyki, o których informują współcześni mieszkańcy wsi. Znajdziemy jednak mapę 775. Magiczne sposoby usuwania przyroku (uroku) - choroby krów, na której opisano m.in. okadzanie, zmywanie, ścieranie i spluwanie (zob. AJKLW-X, cz. 2, 59). Niewiele dowiadujemy się z mapy o zwyczajach na interesującym nas terenie, bo „nie wiadomo, co kobieta robiła, bo nie wolno było patrzeć" (AJKLW-X, cz. 2., 61). Jednak już na mapie 789. Magiczne sposoby usuwania przyroku (uroku) - choroby koni znajdujemy poświadczenie dla praktyki polegającej na zmywaniu choroby szmatą, czemu może towarzyszyć wypowiadanie zaklęcia lub sporządzenie wywaru z ziół (zob. punkt 35 i 35a). Ponadto w komentarzu do tej mapy dla punktu 35. czytamy:

żegnali go miotłą, umaczaną w wodzie, do której dodawali wywar z krwawnika, „krew Jezusa", zwanego też krzyżowym zielem (z kwiatu po ściśnięciu wypływa czerwona ciecz). Kropiąc mówili: „na psa przyrok”. Należy dodać jako komentarz, że zmywanie zostało zastąpione kropieniem (także zabiegiem magicznym). Występuje w tym 
przypadku synkretyzm, czyli połączenie dawnych wyobrażeń z wartościami uznanymi przez religijność ludową (AJKLW-X, cz. 2. 86).

Z przytoczonego fragmentu komentarza atlasowego wynika, że już w latach 70. zwracano uwagę na silny wpływ religijności na przeobrażenia w sposobie wykorzystywania praktyk ludowych. Wrócę jednak do materiałów współczesnych.

Jeśli ktoś nie zbroi się w wyżej zalecany arsenał środków zaradczych, niechybnie prosi się o nieszczęście, które zapewne go dosięgnie i to w niedalekiej przyszłości. Wówczas pechowcowi pozostaje wyłącznie modlitwa. Modlitwa w materiałach słownikowych jest wymieniana stosunkowo często, zapewne $\mathrm{z}$ dwojakich przyczyn: 1. ze wstydu przed przyznaniem się do wiary w zabobony, z poczucia bycia chrześcijaninem, nie wypada więc wyznawać wiary w nadprzyrodzone istoty i zdarzenia albo 2 . z powodu autentycznej wiary czy faktycznego przywiązania do nauki Kościoła, która - jak wiadomo - odrzuca spirytyzm, o ile nie dotyczy on Trójcy Świętej, Matki Boskiej czy innych osób świętych.

Kultura ludowa idzie dziś w parze z obyczajowością wypracowaną na gruncie wiary chrześcijańskiej (ściślej katolickiej), ale i z silnymi wpływami kultury masowej. Cechą charakterystyczną współczesnej obyczajowości w zakresie świąt, wierzeń i przesądów w okolicach Gniezna jest wyraźne nacechowanie ludowych zwyczajów religijnością chrześcijańską. Sytuacja taka nie powinna budzić zdziwienia, gdyż Kościół i ludowość osiągnęły w ten sposób swoisty kompromis - kościół parafialny nie od dziś ma ogromny wpływ na życie mieszkańców w danej wsi. Jednakże to, co dziwić może, to trwanie w XXI w. starych wierzeń i przekonań w niezmienionej postaci, właściwie poza chrześcijaństwem. Możemy obserwować resztki ludowości w chrześcijańskim świecie, bo te najbardziej ludowe zwyczaje znane są i w pełni rozumiane już praktycznie $\mathrm{w}$ grupie najstarszych informatorów (o tym, jak rozkłada się pokoleniowo świadomość kulturowa i językowa opisywanej tu tematyki, warto napisać przy innej okazji).

Na zakończenie dodam - co może nie wybrzmiało wcześniej zbyt wyraźnie - że specyfika badań dialektologicznych wymaga bezpośredniego kontaktu z informatorem. W dzisiejszej rzeczywistości społecznej nie jest łatwo pozyskać osoby skłonne do rozmów, które w dodatku są nagrywane (stąd niejednokrotnie informatorzy nie ujawniają swoich danych osobowych). Dzięki projektom edukacyjnym dialektolog ma możliwość prowadzenia badań w nieznanym terenie, zaangażowani uczniowie uczestniczą w lekcjach o charakterze innowacyjnym, a nauczyciel ma okazję w przyszłości wprowadzić niestandardowe metody nauczania.

\section{Bibliografia:}

AJKLW - Atlas języka i kultury ludowej Wielkopolski, t. I-VI, 1979-1991, Sobierajski Z., Burszta J. (red.), Wrocław [i in.]; t. VII-XI, 1992-2005, Sobierajski Z. (red.), Poznań. 
AJKLW-X - Atlas języka i kultury ludowej Wielkopolski, 2001, t. X: LECZNICTWO LUDOWE. MAGIA, Sobierajski Z. (red.), cz. 1. Mapy 764-834, cz. 2. Wykazy i komentarze do map 764-834, Poznań.

Brencz Andrzej, 2006, Wielkopolski rok obrzędowy. Tradycja i zmiana, Poznań.

Burszta Józef (red.), 1967, Kultura ludowa Wielkopolski, t. III, Poznań.

Gajek Józef (red.), 1964-1981, Polski Atlas Etnograficzny, z. I-VI, Warszawa.

Kłodnicki Zygmunt (red.), 2002, Komentarze do Polskiego Atlasu Etnograficznego, T. 6. Wiedza i wierzenia ludowe, Wrocław-Cieszyn.

Kobus Justyna, 2017, Rola współpracy ze szkołami w badaniach dialektalnych Wielkopolski, w: Wierzbicka-Piotrowska E. (red.), Dialog pokoleń 3, Warszawa, s. 135-142.

Kobus Justyna, 2018, Funkcjonowanie zwyczajów, elementów tradycji i ich nazw wśród mieszkańców wsi okolic Gniezna, w: Wierzbicka-Piotrowska E. (red.), Dialog pokoleń w języku i językoznawstwie, Warszawa, s. 99-111.

Kobus Justyna, Gniazdowski Tomasz, 2018, Słownik języka mieszkańców okolic Gniezna. Święta, wierzenia i przesady, Poznań.

Kobus Justyna, Stępień Magdalena (red.), 2018, Słownik języka mieszkańców okolic Czerniejewa. Praca na roli i w gospodarstwie, Poznań.

Kolberg Oskar, 1877, Lud. Jego zwyczaje, sposób życia, mowa, podania, przysłowia, obrzędy, gusła, zabawy, pieśni, muzyka i tańce. Wielkie Księstwo Poznańskie, Kraków, przedruk w: Kolberg O., Dzieła wszystkie, 1963, t.11. W. Ks. Poznańskie, cz. 3, Wrocław-Poznań.

Nowak Henryk, 1999, Obrzędowa (wigilijna) nazwa gwiazdor i synonimy $w$ Wielkopolsce, w: Nowak H. (red.), Viro Doctissimo Optime Merito - Prace ofiarowane Profesorowi Zenonowi Sobierajskiemu w 80. rocznice urodzin, Poznań, s. 66-80.

Paprot Aleksandra, 2015, Powiat gnieźnieński. Atlas niematerialnego dziedzictwa kulturowego wsi wielkopolskiej, Szreniawa.

Sierociuk Jerzy, 2018, Dokumentowanie dialektu wielkopolskiego - historia, teraźniejszość, perspektywy, referat na konferencję Polszczyzna jako dziedzictwo. W stulecie odzyskania niepodległości, Poznań.

Sierociuk Jerzy, 2016, Słowniki regionalne jako wstępny etap opracowania słownika ogólnowielkopolskiego, w: Rembiszewska D.K. (red.), Słowiańskie słowniki gwarowe - tradycja i nowatorstwo, Warszawa-Łomża, s. 245-254.

Sierociuk Jerzy, 2010, Z problematyki regionalizmów językowo-kulturowych: zając, w: Przybylska R., Kąś J., Sikora K. (red.), Symbole grammaticae in honorem Boguslai Dunaj, Kraków, s. 241-248.

Sobierajski Zenon, 1995, Teksty gwarowe ze środkowej Wielkopolski, Poznań.

Sobierajski Zenon, 2004, Teksty gwarowe ze wsi Żydówko-Łubowo koło Gniezna $w$ Wielkopolsce środkowej (nagrane w roku 1977), „Poznańskie Studia Polonistyczne. Seria Językoznawcza” XI (XXXI), Poznań, s. 153-163.

Sobierajski Zenon, 2004, Zmiany pokoleniowe w gwarach wielkopolskich. 4. Gwara wsi Żydówko-Łubowo koło Gniezna w Wielkopolsce środkowej. Uwagi 
wstępne, „Poznańskie Studia Polonistyczne. Seria Językoznawcza” XI (XXXI), Poznań, s. 143-151.

Tomaszewski Adam, 1930, Gwara Łopienna i okolicy w północnej Wielkopolsce, Kraków.

\section{O Autorce:}

Justyna Kobus - polonistka, dialektolog, absolwentka studiów podyplomowych z archiwistyki i zarządzania dokumentacją. W 2009 roku obroniła pracę doktorską z leksyki wielkopolskiej. W Pracowni Dialektologicznej Uniwersytetu im. Adama Mickiewicza w Poznaniu prowadzi badania terenowe polegające na fonograficznej archiwizacji gwar. Zainteresowania naukowe to leksykologia i leksykografia gwarowa, funkcjonowanie zjawisk fleksyjnych w mowie Wielkopolan oraz ściśle związana z dialektologią etnografia. Od 2015 roku popularyzuje wiedzę o gwarach i kulturze ludowej, prowadząc projekty edukacyjne w szkołach na terenie Wielkopolski. Autorka czterech monografii i ponad 50 artykułów naukowych. 